\title{
AGS 104 -- A New Rye Cultivar for Winter Forage and Silage Production ${ }^{1}$
}

Ann Blount, Ronald Barnett, Jerry Johnson, Cheryl Mackowiak, and Yoana Newman²

AG 104 is a new early winter rye cultivar developed by the University of Florida and the University of Georgia.

The average rye season lasts from December through April in the southeastern US. Some rye cultivars produce early-season forage, while others are typically late-season. Several rye cultivars may be blended or broad-based populations used to produce tonnage fairly evenly over the course of the growing season. AGS 104 was developed for early season forage production, which is well suited for various livestock operations.

Rye production is required more in December, January, and February than in March and April by southeastern livestock producers. Typically by mid-April the summer perennial grasses come out of dormancy and begin to grow. Earlier rye growth accelerates the winter grazing period where early forage production is desirable. It is particularly useful for dairy silage operations where cool-season forages are followed by early-planted corn.
AGS 104 (tested experimentally as: FLPL97P20) originated from an equal mixture of 5 strains that were developed in 1996 at Griffin, GA: Strain 1 = Bates, WALC7 and Florida 401; Strain $2=$ Maton, WALC7 and Florida 401; Strain $3=$ Oklon, WALC7 and Florida 401; Strain $4=$ NF 73, WALC7 and Florida 401; Strain $5=$ BR1, WALC7 and Florida 401. This mixture was selected over a period of years (4 cycles of selection) at Quincy, FL 1998-2001. Bates, Maton, Oklon, and NF 73 were developed by the Samuel Roberts Noble Foundation. The BR1 is a rye from Brazil. The WALC7 is a selection developed from Wrens Abruzzi and was released as Wrens 96. Good forage production, disease resistance and high seed yield were used as selection criteria for advancing each cycle.

AGS 104 has performed well in variety trials throughout the southeastern US, particularly for early season forage production. It also performs well in blends with annual ryegrass for long-season forage production. AGS 104 most closely resembles Wrens 96. It is slightly shorter and earlier than Wrens 96. AGS 104 has good leaf rust resistance. AGS 104 was

1. This document is SS AGR 278 one of a series of the Agronomy Department, Florida Cooperative Extension Service, Institute of Food and Agricultural Sciences, University of Florida. Original publication date October 2007. Visit the EDIS Web Site at http://edis.ifas.ufl.edu.

2. Ann Blount, associate professor, Agronomy Department, North Florida Research and Education Center--Marianna, FL; Ronald Barnett, professor, Agronomy Department, North Florida Research and Eduction Center--Quincy, FL; Jerry Johnson, University of Georgia; Cheryl Mackowiak, assistant professor, North Florida REC - Quincy, FL; Yoana Newman, assistant professor, Agronomy Department; Florida Cooperative Extension Service, Institute of Food and Agricultural Sciences, University of Florida, Gainesville, FL 32611.

The Institute of Food and Agricultural Sciences (IFAS) is an Equal Opportunity Institution authorized to provide research, educational information and other services only to individuals and institutions that function with non-discrimination with respect to race, creed, color, religion, age, disability, sex, sexual orientation, marital status, national origin, political opinions or affiliations. U.S. Department of Agriculture, Cooperative Extension Service, University of Florida, IFAS, Florida A. \& M. University Cooperative Extension Program, and Boards of County Commissioners Cooperating. Larry Arrington, Dean 
released exclusively to AGSouth Genetics for marketing. 